\title{
Family-School Cooperation: An Online Survey of Parents and Teachers of Young Children in Spain
}

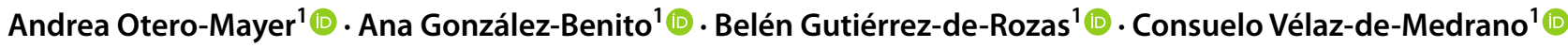

Accepted: 29 April 2021 / Published online: 13 May 2021

(c) The Author(s), under exclusive licence to Springer Nature B.V. 2021

\begin{abstract}
Given the closure of schools due to the global confinement resulting from the COVID-19 crisis, family-school cooperation has become a priority in most educational stages, but especially in Early Childhood Education and Care. This research analysed how parents dealt with this new situation, as well as the way in which family-school cooperation was established. Two online questionnaires were developed by the researchers. Respondents included 1266 families with children between the ages of infancy and six years, as well as 1235 early childhood education teachers from all regions of Spain. Results show that family-school cooperation is associated with several family and school characteristics and that families have neither the tools to face this new situation, nor the time to educate their children at home. This, together with the fact that some households do not have Internet access, makes family-school cooperation a challenging matter, especially in times of pandemic.
\end{abstract}

Keywords COVID-19 $\cdot$ Digital divide $\cdot$ Early childhood education $\cdot$ Parent participation $\cdot$ Parent school relationship $\cdot$ Spain

\section{Introduction}

The health crisis caused by the COVID-19 pandemic has been an exceptional scenario in the educational field, since, at the time of this writing, the closure of schools is affecting $89 \%$ of the student body worldwide (UNESCO, 2020a). This has meant that, suddenly, an alternative system of distance learning had to be implemented at all educational stages in an attempt to minimize the disruption caused by this interruption of the formal education process (United Nations, 2020). Faced with this situation, the Internet and technological media have played a very relevant role in establishing family-school collaboration and in the development of teaching-learning processes.

These measures have affected all levels of education, from the first years of schooling to higher education. The learning rhythm has also been altered in children in Early Childhood Education and Care. This constitutes an essential stage of education, given that $87 \%$ of the brain is formed in the first three years (UNICEF, 2014). Children's development is not

Andrea Otero-Mayer

aotero@edu.uned.es

1 MIDE II, Universidad Nacional de Educación a Distancia (UNED), C/Juan del Rosal 14, despacho 2.26,

28040 Madrid, Spain only affected by aspects of health and nutrition but also by the interactions that they have with people and objects in their environment (Herrera et al., 2006). During early childhood, the basis of human development and personality are established, from which the successive formative stages will be consolidated and perfected (Bodero, 2017).

In European countries, 34\% of children under 3 and $95 \%$ of those over 4 attend school. In the case of Spain, schooling in the 0-3 cycle has doubled in the last 10 years (Ministry of Education and Vocational Training, 2019a). In Spain, as in some other countries, there are two types of educational centres, depending on their ownership; state, which is owned by the government (regional or autonomous) and private (owned by a company). There is a third intermediate option, the state-assisted centres, whose ownership is private, but their financing, at least partially, comes from the government. Likewise, there are first cycle centres $(0-3)$, second cycle centres (3-6), and centres that offer both cycles (0-6).

In the 2020-2021 academic year, there are 9154 Early Childhood Education and Care schools in Spain, 50\% of which are private, although they enroll only $32.1 \%$ of the children (Ministry of Education and Vocational Training, 2020). In the pre-school age group, as age increases, the percentage of children enrolled in centres increases. To illustrate, just $10 \%$ of 1 -year-olds and $58.7 \%$ of 2 year-olds are in centres, but those percentages jump to $96.2 \%$ for 3 -year-olds, 
and $97.1 \%$ for 5-year-olds (Ministry of Education and Vocational Training, 2019b). Thus, centre-based programs are practically universal for 3- to 5-year-olds in Spain.

These data show that the objective of having at least $95 \%$ of children between the ages of four and the starting age of compulsory primary education participating in preschool education by the end of 2020 (Official Journal of the European Union, 2009), has been reached.

The paradigm shift from the care-centre model to the educational model, as well as the increase in schooling in Early Childhood Education and Care, brings with it undeniable benefits for children. This is reflected by the results of the meta-analysis carried out by van Huizen and Plantenga (2018). Here, multiple positive effects are shown in the cognitive area, social-emotional development, or motor skills, especially in children with more unfavourable socioeconomic conditions. Thus, a key role is played by the early childhood education stage as a compensator of differences from the very first moments of education (Bausela, 2019), and by contributing to the guarantee of an inclusive, equitable and quality education, while at the same time providing learning opportunities for all (UNESCO, 2015), and addressing inequities for this group.

Along the same lines, numerous studies support the need for, and the positive effects of cooperation among families and schools, as this is considered to constitute one of the determining factors of the quality of education (European Commission, 2000). In a modern educational system, it is essential that parent-school relationships be understood as proactive cooperation, established between families and teachers to promote the integral development of children. We understand cooperation as a synonym for engagement, defined as goals for children's learning that are shared by teachers and parents (Pushor, 2012). When parents are more engaged, children tend to perform better in school (Van Voorhis et al., 2013). Also when parents and teachers work together, they can provide "optimum opportunities for children to learn and develop" (Whalley, 2017, p. 66). On the other hand, the educational level of the parents constitutes a factor that can be associated with the academic and work development of the children (OECD, 2018) as well as with the degree of participation in the education of their children (Criado et al., 2000; Marchesi, 2003; Valdés et al., 2009), with maternal level of education identified as one of the factors that can most influence children's cognitive development (Reardon, 2011). Thus, this cooperation tends to be associated with improvements in diverse variables such as academic performance (Castro et al., 2015) and socialemotional functioning, leading to a reduction in behavioural problems (Thomson \& Carlson, 2017), as well as more positive peer interaction during play (Besler \& Kurt, 2016).

The responsibility for initiating this approach must be assumed by the school as an educational institution
(Rodríguez-Ruiz et al., 2016; Triana et al., 2019). However, for these results to be truly obtained, the participation of families in the school cannot be reduced to mere representation in the governing structures of the schools (Medina, 1990). The relationship between families and schools must be dynamic and inspiring in order to transform the life and very nature of the school (Horcajo, 1979), so that parents feel interested and involved in the educational processes of their children. Moreover, it requires a special effort to integrate students from the most socially, economically, and culturally disadvantaged sectors of the population into the "democratic culture" of the school (Gil, 1995). In order to involve families in schools and to foster a fluid collaboration (Duddy, 2019), educators must be particularly prepared to respond with appropriate strategies that make the family-school relationship viable in any situation. These strategies include changing the structure and dynamics, or the composition or performance of roles (Rivas-Borrell \& Ugarte-Artal, 2014) and adapting to challenges such as the COVID-19 pandemic. In order to facilitate an adequate interaction between early childhood professionals and children's parents, both professional support and guidance is needed (Ward, 2018).

The consequences of the temporary suspension of activities in early childhood educational centres have affected both families and teachers, with the digital divide and the need to distribute available time between working and educating posing serious problems. Specifically, according to UNESCO (2020b), these consequences stem from unequal access to digital platforms and the lack of preparation of families for distance or home-based teaching. In this regard, UNICEF (2021) highlighted that between March 11th, 2020 and February 2nd, 2021, schools were completely closed for an average of 95 days, which is half an academic year. In addition, the countries that have had closed schools for the most days are the ones that have the least access to the Internet from home.

As seen in other investigations which have been performed in Spain, the school closure has increased inequalities among primary (Cabrera et al., 2020), secondary (Aznar-Sala, 2020), and university students (Rodicio García et al., 2020), and especially in those from disadvantaged families. Similarly, studies focused on early childhood education in other countries also indicate that the lockdown has exacerbated inequalities among low-income families and for children with disabilities (Atiles et al., 2021).

In addition, according UNICEF (2020), "emergencies are becoming more frequent around the world and, moreover, their virulence is increasing" (p.3) and, for this reason, they have proposed an Emergency Cycle. It will help us to be better prepared for future crises like the one being lived with COVID-19. This cycle is composed of the five stages: prevention, mitigation, preparedness, response and, 
finally, recovery. The first stage is prevention, establishing the actions that are taken in advance and that are aimed at avoiding the impact of a possible crisis. The second stage is mitigation, being those actions that seek to limit or reduce the negative impact of the crisis in the first moments. In the third stage, the pillars for reconstruction begin to be put in place. The response to the crisis is the fourth stage of the emergency, which is characterized by the actions taken after the emergency is declared and which are aimed at reducing the impact of the crisis in the short and medium term. Finally, in the recovery stage, the new normal can be resumed, but without forgetting what happened to reduce the impact of future crises.

Therefore, the objective of this study is to analyse parentteacher cooperation in the exceptional situation in which we find ourselves, with infants and toddlers restricted to home. Hence, this work explored how families have responded to this situation, whether they have established contact and collaboration with the schools, and how teachers' knowledge of the digital divide affected said collaboration.

\section{Materials and Methods}

\section{Sample}

The sample selection was carried out by creating a database with more than 5000 schools in all the Autonomous Communities and Cities of Spain that offer first, second cycle or both in Early Childhood Education, having sent them a questionnaire by e-mail during the months of April and May. Schools were requested to collaborate by re-sending it to the families of the children enrolled in this stage. Table 1 shows the distribution by Autonomous Community or City of the schools in the sample.

Specifically, the sample consisted of 1235 educators (90.7\% women and $9.3 \%$ men), $35.7 \%$ of which taught in the first cycle ( $0-3$ years), $56.4 \%$ in the second cycle (3-6 years) and $7.9 \%$ in both simultaneously. Furthermore, most of these teachers worked in state schools (72\%), in contrast to private $(9.1 \%)$ or state-assisted schools $(18.9 \%)$. More than $80 \%$ have maintained their employment status during the COVID-19 health crisis, not having been dismissed or suffered any other relevant change in their employment status.

Information was also collected from 1266 family members of children enrolled in preschool education, of which $87.5 \%$ were mothers, $12.3 \%$ were fathers and $0.02 \%$ legal guardians, all of whom were in charge of children born after 2014. In addition, half of these families had two children, while $42.3 \%$ had one and $7.3 \%$ had three or more.

Finally, it should be noted that the distribution of children by type of school was higher in the case of state schools
Table 1 Distribution (\%) of schools and families by Autonomous Community/City

\begin{tabular}{|c|c|c|c|c|}
\hline \multirow[b]{2}{*}{$\begin{array}{l}\text { Autonomous community/ } \\
\text { City }\end{array}$} & \multicolumn{2}{|c|}{ Frequency } & \multicolumn{2}{|c|}{ Percentage } \\
\hline & Schools & Families & Schools & Families \\
\hline Andalusia & 244 & 184 & 19.8 & 14.5 \\
\hline Aragón & 78 & 24 & 6.3 & 1.9 \\
\hline Asturias & 64 & 47 & 5.2 & 3.7 \\
\hline Balearic Islands & 102 & 147 & 8.3 & 11.6 \\
\hline Canary Islands & 61 & 14 & 4.9 & 1.1 \\
\hline Cantabria & 22 & 5 & 1.8 & 0.4 \\
\hline Castile-La Mancha & 141 & 171 & 11.4 & 13.5 \\
\hline Castile and Leon & 17 & 9 & 1.4 & 0.7 \\
\hline Catalonia & 168 & 144 & 13.6 & 11.4 \\
\hline Ceuta & 13 & 10 & 1.1 & 0.8 \\
\hline Valencian Community & 59 & 171 & 4.8 & 13.5 \\
\hline Extremadura & 41 & 20 & 3.3 & 1.6 \\
\hline Galicia & 26 & 12 & 2.1 & 0.9 \\
\hline Madrid & 57 & 200 & 4.6 & 15.8 \\
\hline Melilla & 3 & 0 & 0.2 & 0.0 \\
\hline Murcia & 8 & 3 & 0.6 & 0.2 \\
\hline Navarra & 21 & 2 & 1.7 & 0.2 \\
\hline The Basque Country & 97 & 100 & 7.9 & 7.9 \\
\hline Rioja & 3 & 0 & 0.2 & 0.0 \\
\hline Not specified & 10 & 3 & 0.8 & 0.2 \\
\hline
\end{tabular}

(59.2\%), with $29.3 \%$ being state-assisted centres and $11.5 \%$ private centres.

\section{Materials}

The present work is part of a survey-type study, so the information was collected through the design and application of two questionnaires: one designed for professionals in educational centres and the other, for families of young children. The teacher survey had 19 items, including closed-ended questions and Likert scales (1-6). It was organized in two sections as follows: the first section was linked to personal and social-labour characteristics of the teachers and consisted of closed-ended questions. The second section of the questionnaire consisted of Likert scale items that measured their own perception of their educational tools, the contact established with the families, and their knowledge of Internet possession of said families. In these scales, the score six corresponds to "totally agree" and one to "totally disagree".

The second questionnaire was aimed at families. It consisted of 28 questions, which also included closed-ended questions and Likert scales. In this case, the dimensions considered in the closed-ended questions which formed the first section were linked to personal and socio-demographic variables of the families. The second section was composed 
of Likert scales-1 to 6-which measured the perception of families about the contact established with schools, the activities and routines followed during the pandemic, their educational tools and wellbeing, and the educational consequences they believed the pandemic could have.

\section{Data Analysis}

The data analysis was performed, firstly, by means of an exploratory examination of the main variables considered. Subsequently, an analysis was carried out by studying, on the one hand, the associations between the time that families have for the education of their children and their educational level. On the other hand, the associations between having or not established contact with the school with each of the following variables were considered: the number of children, their year of birth, the type of school, and the educational level of the families. Finally, the associations between teachers' knowledge of whether families had Internet access to establish said contact with the cycle taught and with the type of centre were studied. After studying the normality of the variables by the Kolmogorov-Smirnov test, a nonparametric analysis was established, using the Kruskal Wallis H-test for quantitative data and the Chi-square test for categorical variables, establishing a significance level of 0.05 .

Finally, logistic regression analyses were carried out to further explore the associations that had proven to be statistically significant, helping to predict the contribution that the variables under consideration have made in predicting the results obtained in the sample. These analyses allowed studying the effects of the categories of independent variables on a dependent dichotomous variable by means of the odds ratio. The statistical package used was SPSS version 25 .

\section{Results}

\section{How Families Deal with It: Establishing Family-School Cooperation}

Survey responses show that $58.2 \%$ of the families considered themselves prepared to become their children's teachersanswers 5 and 6 of the Likert Scale. However, this percentage leaves more than $40 \%$ of families not sufficiently prepared to deal with the changes.

In addition, $17.3 \%$ felt they did not have enough timeanswers 1 and 2 of the Likert Scale-to spend with their children. Kruskal-Wallis H test showed the existence of statistically significant differences according to the educational level of the families, since $\mathrm{p}=0.000<0.05(\mathrm{H}=57.733$; d.f. $=5$ ). In this sense, the data suggested that the families who had a higher level of agreement with the item about having sufficient time to dedicate to the education of their children during confinement were those who had achieved an educational level lower than University, while those who completed higher education had less time to do so $(52.6 \%$ for Primary Education, 49\% for Vocational Training, 50.3\% for Baccalaureate 38\% for Degree, 27.5\% for Master's degree, and $40.7 \%$ for Doctorate).

Although $97.2 \%$ of the families stated that there was a communication channel on the part of the school, there was no communication in $7 \%$ of cases. The Chi-square test did not reveal statistically significant differences for the fact of having established contact with the educational centre according to the number of children $(\chi 2=2.071$; d.f. $=2$; $\mathrm{p}=0.355>0.05)$ or their year of birth $(\chi 2=1.249$; d.f. $=5$; $\mathrm{p}=0.940>0.05)$, but it did show differences in the type of the school attended $\left(\chi^{2}=9.747\right.$; d.f. $\left.=2 ; \mathrm{p}=0.008<0.05\right)$ and the educational level of the families $(\chi 2=12.541$; d.f. $=4 ; p=0.014<0.05$ ).

The results obtained in the association analyses are observed in more detail through the conditional distributions for families' level of contact with school in relation to the type of centre and educational attainment of the families, which are shown in the columns of Table 2.
Table 2 Contact/no contact with families $(\%)$ in relation to type of school and the educational level of families

\begin{tabular}{|c|c|c|c|c|c|c|c|c|c|c|}
\hline \multicolumn{11}{|c|}{ Contact/no contact with families (\%) } \\
\hline & & \multicolumn{3}{|c|}{ Type of school } & \multicolumn{5}{|c|}{ Educational level } & \multirow[t]{2}{*}{ Whole sample } \\
\hline & & State & Private & State-assisted & 1 & 2 & 3 & 4 & 5 & \\
\hline \multirow[t]{2}{*}{ Contact $\%$} & Yes & 91.2 & 97.2 & 94.9 & 86.4 & 91.4 & 94 & 93.9 & 96 & 93 \\
\hline & No & 8.8 & 2.8 & 5.1 & 13.6 & 8.6 & 6 & 6.1 & 4 & 7 \\
\hline
\end{tabular}

Non-compliance with the minimum number of cases for the application of the Chi-square test contrast has made it necessary to group the Master's degree and Doctorate categories into a single Postgraduate category

Educational level: 1 Primary Education, 2 Vocational Training, 3 Baccalaureate, 4 Degree, 5 Postgraduate 
Said analyses of the conditional distributions allow us to identify that state schools were contacted by families less frequently than expected, presenting a negative association $(91.2 \%<93 \%)$. However, this association was positive in the case of private $(97.2 \%>93 \%)$ and state-assisted schools $(94.9 \%>93 \%)$. Likewise, the odds ratios (OR) of the logistic regression (Table 3 ) show that, compared to having children enrolled in a state school, doing so in a private centre multiplies by 3.41 the probability of having contact with the school, while belonging to a state-assisted school multiplies this probability by 1.79 .

On the other hand, the association between such contact and the educational level of the families was negative for parents who had a maximum educational level of Primary Education $(86.4 \%<93 \%)$ or Vocational Training $(91.4 \%<93 \%)$, while families with an educational level of Baccalaureate $(94 \%>93 \%)$, Degree $(93.9 \%>93 \%)$, or Postgraduate studies $(96 \%>93 \%)$ contacted schools to a greater extent than would be expected. Also, the odds ratios in Table 3 show that, compared to parents having an educational level of Primary, having a Baccalaureate level multiplied the probability of establishing contact with the school by 1.66 , while having a Degree multiplies said probability by 2.41, and having Postgraduate studies multiplies it by 6.38 .

\section{The Role of the Internet in Family-School Cooperation: Teachers' Perceptions}

The role of the Internet at home was also analysed in this study, given its relevance not only in enabling children to adequately follow the academic year during confinement, but also in allowing for the establishment of parent-school collaboration. We found that although $97.9 \%$ of households had
Internet access in their homes, schools face difficulty with family communication with a small percentage of families, since $2.1 \%$ of households did not have this service.

Regarding teachers' perception that the lack of Internet in homes was the main barrier to the establishment of contact: $35.5 \%$ considered that a lack of the Internet was not the main reason why families did not contact the school, $33.3 \%$ were of the opinion that around 10\% of families did not establish contact with the school because of the lack of this service, $9.4 \%$ thought that $20 \%$ of the families did not contact the school because they did not have Internet, and the rest of the teachers considered that this was the main cause for a lack of contact in a higher percentage of families.

In addition, only $81 \%$ of the teachers knew the situation in which the families found themselves in relation to Internet ownership, and the Chi-square test revealed the existence of statistically significant differences in this fact between the different groups based on the ownership of the schools $(\chi 2=41.344 ;$ d.f. $=2)$ and the type of program in which the teachers were working $(\chi 2=129.063$; d.f. $=2)$, since $\mathrm{p}=0.000<0.05$ in both cases.

Furthermore, columns in Table 4 show the conditional distributions for knowing or not knowing about the possession of the Internet by families for each school type and each cycle taught.

In this case, analyses of the type of association between the modalities of the characteristics have also been carried out. This analysis showed that there was a positive association between having knowledge of the families' situations with respect to Internet access and the fact that the educational centre is state financed. Hence, teachers in state schools knew this information to a greater extent than expected $(85.4 \%>81 \%)$. However, this association was
Table 3 Logistic regression for type of school and educational level depending on the establishment of contact with families

\begin{tabular}{|c|c|c|c|c|c|c|c|c|}
\hline \multicolumn{9}{|c|}{ Establishment of contact with families } \\
\hline & \multicolumn{3}{|c|}{ Type of school } & \multicolumn{5}{|c|}{ Educational level } \\
\hline & State & Private & State-assisted & 1 & 2 & 3 & 4 & 5 \\
\hline OR & & 3.41 & 1.79 & & 1.66 & 2.48 & 2.41 & 6.38 \\
\hline $95 \% \mathrm{CI}$ & & $(1.22,9.5)$ & $(1.06,3.03)$ & & $(0.84,3.3)$ & $(1.05,5.82)$ & $(1.28,4.53)$ & $(1.56,9.1)$ \\
\hline $\mathrm{p}$-value & & 0.019 & 0.030 & & 0.146 & 0.038 & 0.007 & 0.000 \\
\hline
\end{tabular}

Educational level: 1 Primary Education, 2 Vocational Training, 3 Baccalaureate, 4 Degree, 5 Postgraduate

\begin{tabular}{|c|c|c|c|c|c|c|c|c|}
\hline \multicolumn{9}{|c|}{ Knowledge/no knowledge (\%) of internet possession by families } \\
\hline & & \multicolumn{3}{|c|}{ Type of school } & \multicolumn{3}{|l|}{ Cycle } & \multirow[t]{2}{*}{ Whole sample } \\
\hline & & State & Private & State-assisted & First (0-3) & Second (3-6) & Both & \\
\hline \multirow[t]{2}{*}{ Contact\% } & Yes & 85.4 & 66.1 & 71.4 & 63.9 & 90.4 & 90.7 & 81 \\
\hline & No & 14.6 & 33.9 & 28.6 & 36.1 & 9.6 & 9.3 & 19 \\
\hline
\end{tabular}

Table 4 Knowledge/no knowledge (\%) of Internet possession by families for type school and each cycle 
negative in the case of private schools $(66.1 \%<81 \%)$ and state-assisted schools $(71.4 \%<81 \%)$. Furthermore, the OR of the logistic regression (Table 5) showed that working in a state-assisted school or in a state school seemed to hinder teachers in knowing about the Internet ownership of families by 0.334 and 0.427 , respectively.

The association between having said knowledge and the cycle taught was positive for teachers who taught both cycles (infant-6 years) $(90.7 \%>81 \%)$ or second cycle (3-6 years) $(90.4 \%>81 \%)$, being lower than expected for those who taught in the youngest age group (infant -3 years) $(63.9 \%<81 \%)$. In this vein, the odds ratios in Table 5 show that teaching in the second cycle or in both cycles multiplies the probability of knowing this information by 5.3 and 5.51 respectively in relation to teaching in the first cycle.

\section{Discussion}

These findings should impel us to work to improve familyschool cooperation, and this relationship must begin at the start of the child's education. Numerous studies highlight the importance of this relationship, that has positive effects on children's academic performance and social development, and note that high levels of family engagement affect the entire educational community (Castro et al., 2015; Thompson \& Carlson, 2017). Cooperation is based on communication—in this case through digital media - between teachers and parents. For this reason, we analysed the extent of this communication. The integral development of children is possible through the collaboration and commitment of all educational agents, including the children's families. For this to occur, the latter must feel that they are meaningfully involved in the educational project of their children's school.

Given the special situation of school closures and confinement, family-school cooperation has become a priority. We, therefore, decided to analyse the consequences of the closure of preschool centres in Spain, as recommended by UNESCO (2020b). We further considered the relationship established with families through the Internet and, given that confinement had forced families to assume responsibility for teaching, the ways that families dealt with this.
During situations of school closures and teleworking, there are studies (Giménez-Dasí et al., 2020; Jiao et al., 2020) showing that no differences in the psychological wellbeing of pre-schoolers have been observed, and that families with children reported greater well-being than families without children (Möhring et al., 2021). Our results show that the lack of preparation of families to face this situation (UNESCO, 2020b) has highlighted the educational role played by the schools in this stage $(0-6)$, since the results show that $58.2 \%$ of families were prepared to become their children's teachers-answers 5 and 6 on the Likert scale. In this sense, Campos and Vieira (2021) observed how parents have missed school support and how teachers have not had sufficient technological skills to deal with this new situation. Also, time was an important variable and almost $20 \%$ of families reported that they did not have enough time to dedicate to the education of their children, especially among those parents who had attained graduate level education.

During this confinement situation, we analysed how contact with the centre was established and maintained. Only $7 \%$ of the families had no contact with the centre. Our results show that this was influenced, not by the number of children in the family or their year of birth but by the type of school and cycle. Families with higher education and whose children go to private schools are the ones that have had more contact with schools. At this point, it is necessary to stress that, although families with a lower level of education stated having more time for the education of their children, they were the ones who established less contact with schools. For all these reasons, improving the collaboration of families and schools has become a crucial issue in education.

Also, confinement has revealed two initial problems: firstly, the lack of preparation on the part of educators and families to work in a coordinated manner in the education of children since, as Cheng et al. (2020) state, school, teachers, families, and students were "passively separated in space" (p. 843) during confinement. Therefore, Buza and Hysa (2020) found that the use of appropriate communication channels had a positive impact on this communication. Secondly, the serious problem of the digital divide exacerbates inequities since, as pointed by Cabrera (2020), online education can contribute to the level of inequity of educational opportunities. It should also be noted that the role of gender
Table 5 Logistic regression for type of school and cycle taught depending on the knowledge of Internet possession

\begin{tabular}{|c|c|c|c|c|c|c|}
\hline \multicolumn{7}{|c|}{ Knowledge/no knowledge (\%) of internet possession by families } \\
\hline & \multicolumn{3}{|c|}{ Type of school } & \multicolumn{3}{|c|}{ Cycle } \\
\hline & State & Private & Private-state-assisted & First & Second & Both \\
\hline OR & & 0.33 & 0.43 & & 5.3 & 5.51 \\
\hline $95 \% \mathrm{CI}$ & & $(0.22,0.51)$ & $(0.3,0.6)$ & & $(3.86,7.29)$ & $(2.7,11.25)$ \\
\hline p-value & & 0.000 & 0.000 & & 0.000 & 0.000 \\
\hline
\end{tabular}


continues to be very present in these initial stages, given that $87 \%$ of those answering the questionnaires were mothers and $90.7 \%$ of the educators in our sample were women.

The results show that $97.9 \%$ of the 1266 households had access to the internet; however, this is to be expected, given that an online survey was the method of data collection. These data coincide with those published by the National Institute of Statistics of Spain (INE, 2019), in which 97\% of Spanish households with children are recorded to have access to the Internet. This leaves out $2.1 \%$ or $3 \%$ of children and families, who tend to be the ones with lower incomes (INE, 2019). The results also indicate that one in three teachers believe that $10 \%$ of families in their centre have not established contact due to lack of access, but $10 \%$ of educators believe that this figure corresponds to $20 \%$ of families. These data coincide with the results of the PISA 2018 report published by the High Commission for the fight against child poverty (2020), which indicate that, in Spain, one in every five children does not have a computer at home to do their homework. Furthermore, communication was only established in $93 \%$ of cases, meaning that $7 \%$ of the children did not receive any schooling during the last 4 months of the 2019-2020 academic year. These lost opportunities to learn surely will have long-term consequences.

The results show that the ownership and the cycle of the centres influences whether families have the possibility of being connected or not. Only $66 \%$ of private schools know the situation of the families and with respect to the cycle, $63 \%$ of the centres that teach the first cycle know the situation in which their children are with respect to the possibility of contacting the Internet.

\section{Implications and Recommendations}

The data has been analysed, we can make a series of recommendations for various levels (political, educational, and research) that, following the stages of the Emergency Cycle provided by UNICEF (2020), allow us to have a better structured prevention stage, preparing us to face future emergencies in a more positive way for schools-families-students.

At the educational level, since most families do not feel prepared enough to be their children's teachers, the role of the teacher is foregrounded. Therefore, we propose that there be a strengthening of the tutoring in the classroom that allows personalized monitoring of children. Also, given the preventive approach adopted (UNICEF, 2020), to promote the same cooperation between families and schools in future emergencies, regardless of the level of training of families or the ownership of the centres, would be desirable. This improvement in cooperation between families and schools through the tutoring functions will allow families to feel ready to face possible future confinements. These tutoring functions should be promoted through continuous training for teachers, as well as through initial training.

At the political level, we propose a provision of computer equipment to families in need, as well as aid to pay for Internet connections, in order to prevent the digital divide from exacerbating existing inequities.

As a future line of research, it would be interesting to know the state of the participation of families in Early Childhood Education in Spain, in order to promote concrete actions that lead to improved involvement. In this vein, it is also important to promote real cooperation between families and teachers and to prevent the digital divide from becoming an educational divide, as the lack of preparation of families and teachers to work together on improving the educational development of children in Early Childhood Education, as well as the digital divide, have made it difficult for families and teachers to cooperate and, thus, to achieve equal opportunities for children.

Lastly, this research has allowed to have an overview of the situation that has been experienced in Spain with respect to the cooperation between families and schools of Early Childhood Education during the school closures. We have also proposed future lines of action. Nevertheless, the fact that the sample has been collected in the Spanish territory can make it difficult to extrapolate the results to very different contexts, so more research is needed in other locations.

Data Availability Families' answers: Google Forms https://docs.google. com/forms/d/1eLc1zaf6BmFEsBGtVu9834HYS9z2wSUbBghXuLD $\mathrm{cHlQ} /$ dit?usp=forms_home\&ths=true. Educators answers: Google Forms https://docs.google.com/forms/d/1Qc0H9RaUwowrnMDXPVf QEx2ddA9_KpPqk1r5-5W77MY/edit?usp=forms_home\&ths=true

\section{References}

Atiles, J. T., Almodóvar, M., Chavarría Vargas, A., Dias, M. J., \& Zuniga Leon, I. M. (2021). International responses to COVID19: Challenges faced by early childhood professionals. European Early Childhood Education Research Journal, 29(1), 66-78.

Aznar-Sala, F. J. (2020). La Educación Secundaria en España en Medio de la Crisis del COVID-19. RISE, 9(1), 53-78. https://doi.org/10. 17583/rise.2020.5749

Bausela, E. (2019). ¿Qué papel tiene la asistencia a Educación Infantil en la predicción del rendimiento matemático en PISA? Magister, 31(1), 1-16. https://doi.org/10.17811/msg.31.1.2019.9-16

Besler, F., \& Kurt, O. (2016). Effectiveness of video modeling provided by mothers in teaching play skills to children with autism. Educational Sciences: Theory and Practice, 16(1), 209-230.

Bodero, C. (2017). La neurociencia en la primera infancia. Apuntes De Ciencia y Sociedad, 7(1), 6-10. https://doi.org/10.18259/acs. 2017002

Buza, V., \& Hysa, M. (2020). School-family cooperation through different forms of communication in schools during the Covid-19 pandemic. Thesis, 9(2), 55-80. 
Cabrera, L. (2020). Efectos del coronavirus en el sistema de enseñanza: aumenta la desigualdad de oportunidades educativas en España. Revista De Sociología De La Educación-RASE, 13(2), 114-139.

Cabrera, L., Pérez, C., \& Santana, F. (2020). ¿Se incrementa la desigualdad de oportunidades educativas en la Enseñanza Primaria con el cierre escolar por el coronavirus? International Journal of Sociology of Education, 0, 27-52. https://doi.org/10.17583/rise. 2020.5613

Campos, M., \& Vieira, L. (2021). COVID-19 and early childhood in Brazil: Impacts on children's well-being, education and care. European Early Childhood Education Research Journal, 29(1), 125-140. https://doi.org/10.1080/1350293X.2021.1872671

Castro, M., Expósito-Casas, E., López-Martín, E., Lizasoain, L., Navarro-Asencio, E., \& Gaviria, J. L. (2015). Parental involvement on student academic achievement: A meta-analysis. Educational Research Review, 14, 33-46. https://doi.org/10.1016/j.edurev. 2015.01.002

Cheng, X., Pellegrini, M., Zhou, L., \& Cheung, A. C. (2020). Not only survival but stronger: The impact of alarming invader of SARSCoV-2 on global education. Science Insights Education Frontiers, 7(2), 835-860. https://doi.org/10.15354/sief.20.or061

Criado, E., Palomares, F., \& Bueno, C. (2000). Éxito escolar y familias de clase obrera. In L. Samper (Ed.), Familia, cultura y educación. (pp. 35-58). Universidad de Lleida.

Duddy, E. (2019). Parent participation in early years settings in Northern Ireland: Identifying the key themes in 'becoming involved.' European Early Childhood Education Research Journal, 27(5), 675-692. https://doi.org/10.1080/1350293X.2019.1652397

European Comission. (2000). Indicators on the quality of school education. Brussels: Directorate-General for Education and Culture.

Gil, F. (1995). Investigando las relaciones familia-escuela. La participación de los padres en el centro. Aula, 6, 67-76.

Giménez-Dasí, M., Quintanilla, L., Lucas-Molina, B., \& SarmentoHenrique, R. (2020). Six weeks of confinement: Psychological effects on a sample of children in early childhood and primary education. Frontiers in Psychology, 11, 590463. https://doi.org/ 10.3389/fpsyg.2020.590463

Herrera, M. O., Mathiesen, M. E., \& Domínguez, P. (2006). Evaluación de entornos educativos en centros parvularios para menores de tres años: la Escala ITERS. Investigaciones En Educación, 6(1), 141-168.

High Commission for the fight against child poverty (2020). Brecha digital y pobreza infantil. Documento breve 14. Gobierno de España.

INE. (2019). Encuesta sobre Equipamiento y Uso de Tecnologías de Información y Comunicación en los Hogares. INE Notas de prensa.

Jiao, W. Y., Wang, L. N., Liu, J., Fang, S. F., Jiao, F. Y., PettoelloMantovani, M., \& Somekh, E. (2020). Behavioral and emotional disorders in children during the COVID-19 epidemic. The Journal of Pediatrics, 221, 264-266.e1. https://doi.org/10.1016/j.jpeds. 2020.03.013

Malta Campos, M., \& Vieira, L. F. (2021). COVID-19 and early childhood in Brazil: Impacts on children's well-being, education and care. European Early Childhood Education Research Journal. https://doi.org/10.1080/1350293X.2021.1872671

Marchesi, Á. (2003). El fracaso escolar en España. Documento de trabajo. Fundación Alternativas.

Medina, R. (1990). La educación personalizada en la familia. Rialp.

Ministry of Education and Vocational Training. (2019a). Las cifras de la educación en España Estadísticas e indicadores. Edició 2019. Secretaría General Técnica.

Ministry of Education and Vocational Training (2019). Sistema estatal de indicadores de la educación. Madrid: Secretaría General Técnica. Retrieved from: http://www.educacionyfp.gob.es/dam/jcr: 627dc544-8413-4df1-ae46-558237bf6829/seie-2019.pdf
Ministry of Education and Vocational Training (2020). Datos y cifras. Curso escolar 2020-2021. Madrid: Secretaría General Técnica. Retrieved from http://www.educacionyfp.gob.es/dam/ jcr:89c1ad58-80d8-4d8d-94d7-a7bace3683cb/datosycifras 202 1esp.pdf

Möhring, K., Naumann, E., Reifenscheid, M., Wenz, A., Rettig, T., Krieger, U., Friedel, S., Finkel, M., Cornesse, C., \& Blom, A. (2021). The COVID-19 pandemic and subjective well-being: Longitudinal evidence on satisfaction with work and family. European Societies, 23, S601-S617. https://doi.org/10.1080/14616 696.2020 .1833066

OECD. (2018). Education at a Glance 2018: OECD Indicators. OECD Publishing.

Official Journal of the European Union (2009). Council conclusions of 12 May 2009 on a strategic framework for European cooperation in education and training (ET 2020). Retrieved from https://eurlex.europa.eu/legal-content/EN/ALL/?uri=celex\%3A52009XG0 $528 \% 2801 \% 29$

Pushor, D. (2012). Tracing my research on parent engagement: Working to interrupt the story of school as protectorate. Action in Teacher Education, 34(5), 464-479. https://doi.org/10.1080/ 01626620.2012 .729474

Reardon, S. F. (2011). The widening academic achievement gap between the rich and the poor: New evidence and possible explanations. In G. J. Duncan \& R. M. Murnane (Eds.), Whither opportunity? Rising inequality, schools, and children's 76 family life chances. (pp. 91-116). Russell Sage Foundation.

Rivas-Borrell, S., \& Ugarte-Artal, C. (2014). Formación docente y cultura participativa del centro educativo: claves para favorecer la participación familia-escuela. ESE. Estudios Sobre Educación, 27, 153-168. https://doi.org/10.15581/004.27.153-168

Rodicio García, M. L., Ríos-de Deus, M. P., Mosquera-González, M. J., \& Penado Abilleira, M. (2020). La brecha digital en estudiantes españoles ante la Crisis de la Covid-19. Revista Internacional De Educación Para La Justicia Social, 9(3), 103-125.

Rodríguez-Ruiz, B., Martínez-González, R. A., \& Rodrigo, M. J. (2016). Dificultades de las Familias para Participar en los Centros Escolares. Revista Latinoamericana De Educación Inclusiva, 10(1), 79-98. https://doi.org/10.4067/S0718-73782016000100005

de Horcajo, J. J. S. (1979). La gestión participativa en la enseñanza. Narcea.

Thomson, R. N., \& Carlson, J. S. (2017). A pilot study of a selfadministered parent training intervention for building preschoolers' social-emotional competence. Early Childhood Education Journal, 45(3), 419-426.

Triana, B., Ceballos, E., \& Rodríguez, J. A. (2019). Expectativas del futuro profesorado de Educación Infantil y Primaria sobre el desarrollo infantil en distintas estructuras familiars. Aula Abierta, 48(1), 67-76. https://doi.org/10.17811/rifie.48.1.2019.67-76

UNESCO. (2015). Education for all 2000-2015: Achievements and challenges. UNESCO.

UNESCO. (2020a). Covid-19 school closures around the world will hit girls hardest. Retrieved from: https://en.unesco.org/news/covid19-school-closures-around-world-will-hit-girls-hardest

UNESCO. (2020b). Adverse consequences of school closures. Retrieved from: https://en.unesco.org/covid19/educationrespon se/consequences

UNICEF. (2014). Building better brains: New frontiers in early childhood development. UNICEF.

UNICEF. (2020). COVID-19: reimaginar la educación. Aprendizajes de la pandemia sobre los que construir un pacto por la educación. UNICEF España.

UNICEF. (2021). COVID 19 and school closures. One year of education disruption. UNICEF.

United Nations (2020). Diez recomendaciones para estudiar a distancia durante la emergencia del coronavirus Covid19. UN News, 
published March 14 2020. https://news.un.org/es/story/2020/03/ 1471342

Valdés, A. A., Martín, M. J., \& Sánchez, P. A. (2009). Participación de los padres de alumnos de educación primaria en las actividades académicas de sus hijos. Revista Electrónica De Investigación Educativa, 11(1), 1-17.

van Huizen, T., \& Plantenga, J. (2018). Do children benefit from universal early childhood education and care? A meta-analysis of evidence from natural experiments. Economics of Education Review, 66, 206-222. https://doi.org/10.1016/j.econedurev.2018.08.001

van Voorhis, F. L., Maier, M. F., Epstein, J. L., \& Lloyd, C. M. (2013). The impact of family involvement on the education of children ages 3 to 8: A focus on literacy and math achievement outcomes and social-emotional skills. MDRC.
Ward, U. (2018). How do early childhood practitioners define professionalism in their interactions with parents? European Early Childhood Education Research Journal, 26(2), 274-284. https:// doi.org/10.1080/1350293X.2018.1442043

Whalley, M. (2017). Involving parents in their children's learning: A knowledge-sharing approach. Sage. https://doi.org/10.4135/97814 46278888

Publisher's Note Springer Nature remains neutral with regard to jurisdictional claims in published maps and institutional affiliations. 